\title{
The Tragedy Implication in the Religious Thoughts for Journey to the West
}

\author{
Jia-yin QU \\ English Department, Valparaiso University, IN, USA
}

Keywords: Journey to the West, Tragic theme, Combination of three religions

\begin{abstract}
Author explored and analyzed the tragic theme of novel of Journey to the West from the different religious aspects, Buddhism, Confucianism, Taoism and "Combination of three religions". Wu Cheng'en wrote in a humorous tone to disclose the ugly realities and he wanted to save the decadent feudal society in religious ways. But the author himself had found the illusory of religions at same time, which made him helpless. The research results would help well comprehend the theme of Journey to the West from religious views, and provide reference for creative writing. This also enriched the religious terms of tragic researches.
\end{abstract}

\section{Introduction}

One of religious history's greatest triumphs- Xuanzang going on a pilgrimage for the Buddhist Scriptures, was an abundant inspiration for Wu Cheng'en, which helped him created the novel of Journey to the West. It was a romantic and mythological novel, one of the Four Great Classical Novels in Chinese literature history. Scholars hold different views on the themes of Journey to the West. Most of them discussed the comic connotation about Journey to the West, though there is the abundant tragedy implication in the novel, but they rarely explore it. In this paper, the author will explore and analyze the tragic theme of Journey to the West from the different religious aspects, Buddhism, Confucianism, Taoism and "Combination of three religions". The research results would help comprehend the theme of Journey to the West from religious views, and provide reference for creative writing. This also enriched the religious terms of tragic researches.

\section{The Tragedy Implication of "Combination of Three Religions"}

Journey to the West, a classic Chinese fantasy novel, was written in middle Ming Dynasty. The story reflects the social reality at that time such as political corruption, poor people, and religious policies and so on. Taizu of Ming, Zhu Yuanzhang proposed the idea of combination of three religions and made it as fundamental religious policy for Ming Dynasty [1]. Journey to the West takes Chinese traditional culture as the basis, and the novel is the crystallization of social background and cultural context of Ming Dynasty. According to this idea, "combination of three religions" plays an important role in the theme of this work.

The mainstream religious phenomenon of Ming Dynasty- "combination of three religions" is that "Confucianism collaborates with Buddhism and Taoism, and included religious ways". "Combination of three religions", does not mean that these three religions work something like One of Three Roles on a flow of thought in Ming Dynasty, but the three ideas have their own emphasizes. Confucianism, as the value orientation of Ming Dynasty's mainstream society, is also the Tang Monk's measurement criteria when he tells right from wrong and judges the people, so Confucianism plays the most basic guidance function in the ideological system, and 
dominates behaviors of the people in Ming Dynasty as their moral standards. Sun Wukong once studied under Master Bodhiand learned seventy-two different forms and the key to gain immortality. But even he had boundless magic power and eternal life through the exercises of Taoism, it was just the first step to embark on a pilgrimage to India to obtain Buddhist scriptures. By this taken, Taoism is just a means to gain peace and recuperation, however, the ultimate purpose of the master and his three appetencies is to become Buddha, all the hardship they suffered and the devils they defeated on their journey are just for the highest pursuit. In the novel, Buddhist take over everything, which expresses that Buddhist is the ultimate goal that mainstream society pursue. The novel generated from fertile field- Chinese traditional culture, and "combination of three religions" gives enough nutrients to the topic as well.

The master Bodhi who taught Sun Wukong a lot, his name was with a Buddhist meaning, and he had inspirational temperament, but he regarded Confucianism as the criterion. Master Bodhi was shaped as a celestial being that was not only proficient in Taoism and Buddhism: he has many disciples, and taught them a lot. He was greatly respected by people, not only because he taught Taoism, but also helped people build their bodies. The way that the author shaped the characters catered the mainstream ideology [2].

"Combination of three religions", seemed to be very ideal and happy, but the so-called ideal would suffer some blows during the process of making dreams come true all the time. Firstly, though Confucianism is the basis of "combination of three religions", but in Ming Dynasty, Confucianism was interfered by the despotism, which was reflected in the novel. Mukden area encountered great drought for three years, just because a sheriff broke the Jade Emperor's tribute and then the Emperor was in a violent rage and brought the drought to the county. The Emperor ignored common people just for the sake of a small mistake. And the Emperor on the ground also could not get out of the despotism, the king of Buddhist Kingdom used children's hearts as a guiding drug as he heard and believed slanders. This was just for the Emperor's own demand, and he totally did not care about common people. It was so-called Taoism that could not help people build their bodies as Taoism lost its origin. In the Chechi kingdom, the so-called Taoist priests were snobbish people that persecuted Buddhist. And in the Huanghua temple, centipede monsters pretended the false Taoist priests. No one could distinguish truth from falsehood, the idea of building bodies and thoughts had already changed. The mainstream society pursued to comprehend Buddhism, but this dream was corroded by the social reality. Those fowls and beasts, surrendered by Buddha, also watched for some chances to transform into monster to do evils.

"Combination of three religions", took Confucianism as the starting point, and kept Taoism as methodology, set Buddhismas the central theme. This was a perfect imagination at first, but the society background had already settled down a tragedy. Ming Dynasty was the decline period of feudal society. Author used his novel to expose the malady of the real society. $\mathrm{Wu}$ Cheng'en put his abundant life and social experiences into novel and made it more vividly and profoundly, and these eccentric plots reflected the author's a tragedy attitude towards the decline of this feudal society.

\section{The Tragedy Implication of Confucianism}

It was aforementioned that Confucianism was the origin of "Combination of three religions" and the criterion when the figures handled affairs. Firstly, Tang Monk went to India for Buddhist scriptures as he was asked by Emperor Taizong of Tang, and the purpose of this 
journey related to consolidating his governance. "I received great benefit from Emperor Taizong, so I had to dedicate myself to the service of my own country." His words proved the reason that Tang Monk went west was "patriotic and loyal to the throne", which belonged to Confucianism. In this way, the essence of going on a pilgrimage for Buddhist scriptures had some similarities with Confucianism- "regulate the family and rule the state"[3]. During the journey, they expressed the thoughts alteration on entering political stratum through fighting with monsters. Sun Wukong was totally obedient, even Tang Monk misunderstood him, he never blamed on his master. He asked his junior fellows to protect their master, and came back to save Tang Monk's life as all previous ill would have been removed.

After Emperor $\mathrm{Wu}$ implemented the policy "Ban from other philosophers, venerate Confucianism only", Confucianism centered in the ruling thought of feudal society. However, with the gradual exposure of feudal absolute monarchy, the original core of Confucianism"kindheartedness" lost its identity because of the corrupt system. In the novel, the Emperor of Buddhist Kingdom used thousands of children's hearts as guiding drugs to cure diseases, and the king of Miefa kingdom killed ten thousands of Monks just for redeeming his vow to the Jade Emperor. These emperors were all fatuous extremely, and there was nothing about "kindheartedness" at all; public morals and mores were getting worse day by day, demons and ghosts had absolutely no respect for the law and raised the devil. These plots seemed to be bizarre and motley, in fact, Wu Cheng'en wanted to express his tragedy feelings by facing to Confucianism in that social reality as feudal system declined and feudal emperors were fatuous.

\section{The Tragedy Implication of Taoism}

Taoism culture made up most of the novel. At first, Sun Wukong took Master Bodhi as his teacher, and learnt Taoism Kongfu, seventy-two different forms and somersault cloud. Just like Buddhain Western Pure Land of Ultimate Bliss, there were celestial beings in heavens such as the Jade Emperor, Lao Jun, and so on. Celestial beings and their troops caught Monkey King together, and he also practiced penetrating insight in Eight Trigrams Furnace so that he could see through all sorts of evil spirits [4].

But Wu Cheng'en did not show friendly attitude towards Taoism, even gave rising to special attacks. Taoist priest controlled the country and committed primes. The Emperor of Wuji Kingdom was friendly with diabolism, and this diabolism not only killed the Emperor but also forcibly occupied Emperor Throne. And the Emperor of Chechi Kingdom regarded three diabolisms as the Mentor of his country, and Taoism was being elected as the ruling thought, so many Buddhist became slaves by doing menial work for Taoism. The ugliness of Taoism lied in that Taoism advocated the illusory eternity beyond time, but the author had the critical attitude towards Taoism [5]. Actually, he had given rising to disclose and assail the feudal system. But the author did not break through Confucianism, so he just showed the helpless regret.

\section{The Tragedy Implication of Buddhism}

The plot mainline of the novel is describing that Tang Monk with his three apprentices went on a pilgrimage for the Buddhist Scriptures. The process of going through difficulties and dangers, subduing demons and monsters, reflected the reality that Buddhist cultivated morality and comprehended, and then finally became the Buddha. The thoughts and culture of Buddhism are inundated with the whole novel. Tang Monk was the most faithful propagator and kept propagating the Buddhism on the journey: he scrupulously abided by the sacred rules of the 
religious order, and he did not eat meat, did not kill livestock, and did not have lewd conduct. Sun Wukong was punished for the compelling killing livestock, and Tang Monk also severely criticized the Zhu Bajie as he was lazy and fond of good food, and he was also addicted to drink and sex [6]. When they suffered from some disasters that even Sun Wukong could not settle down, Monkey King would ask Bodhisattva and Buddha for help.

Buddhism is the soul of Journey to the West. From the author's view, Buddhism totally outmatched Confucianism and Taoism. Sun Wukong could not escape the palm of Buddha though Confucianism and Taoism had no way to him. Tang Monk and his apprentices finally arrived at India and became Buddha, which all reflected the compliments and appreciation of Buddhism. Even Wu Cheng'en spent so many words on speaking highly of Buddhism, we still could find out the author faintly complained about Buddhism [7]. Many monsters that had boundless supernatural power were the lad or mount of Buddha themselves. A lion monster and an elephant monster were the mount of Manjusri and Samantabhadra separately, and they came down to earth and turned ghosts into human to control the Shituo kingdom. When Sun Wukong and his fellow apprentices fought against the monsters but failed, and Sun Wukong had to ask Buddha for help, finally the monsters were surrendered. With the help of these plots, Wu Cheng'en exposed that Buddhism and Taoism were just illusory, and expressed that he felt downhearted about the society.

\section{Conclusions}

The author have disclosed and discussed the novel Journey to the West from the different religious aspects. Wu Cheng'en described the story in a stimulating style of writing which made even merry laughter and angry shouting delightful reading, but actually the profound tragic theme was hidden under the cynical attitude. In the ending of Journey to the West, Tang Monk and his three apprentices had all become Buddha as a perfect destination. But the rewarding of a hollow title was really the teasing to self-value after eighty-one adventurous experiences. Wu Cheng'en disclosed the ugly realities and wanted to change the decadent feudal society in religious ways. However, Wu Cheng'en himself finally had found the illusory of religions, while he could not find other ways to change. That would be the biggest tragedy in this novel.

\section{References}

[1] Zhang Yijun, The tragic theme of Journey to the West, Master Pieces Appreciation, 6 (2010) 47-49.

[2] Liu Luxing, The tragic theme of Journey to the West in the modern time. Higher Vocational Education in Gansu, 16 (2010) 106-108.

[3] Yu Yingshi, Confucianist and Chinese Culture, Shanghai, Shanghai People Publishing House, 2003.

[4] Wu Cheng'en, Journey to the West, Henan, Yue Lu Academy, 1995.

[5] Lu Xun, Lu Xun Essays Complete Work, Henan, Henan People Publishing House, 1994.

[6] Lu Xun, Brief History of Chinese Fiction, Beijing People Publishing House, 1973.

[7] Zhou Xianshen, Fictions of the Ming and Qing dynasties, Beijing, Peking University Press, 2003. 